\title{
Sense of Loss in Albee's Plays
}

\author{
Kadhim Hatem Kaibr, Guo Jingjing \\ School of Foreign Languages, English Dept, Huazhong University of Science and Technology \\ Hubei Province, Wuhan City, China. \\ kadhim_kaber@yahoo.com \\ guojj@hust.cn
}

\begin{abstract}
In most of his plays, Albee focused on the themes of loneliness, alienation, lack of social communication, family disintegration, loss, anxiety about the future, and absence of human ideals. Some of these plays also reflected the troubled life of Albee, particularly during his childhood and adolescence. The repeated inclusion of anxiety and loss in most of Albee's plays illustrates the suffering faced by individuals in the American capitalist society after the Second World War and reflects some parts of Albee's personal life.This paper will attempt to identify the reasons that encourage Albee to include anxious characters with a sense of loss in most of his literary plays by studying the state of American society in Albee's period and by examining how his previous experiences affect the themes presented in his works.
\end{abstract}

Keywords: Edward Albee, American Society, American Dream, Loss, Anxiety

\section{ImpaCt OF THE AMERICAN MATERIAListic Society}

The Second World War profoundly affected the lives of Americans in the military and challenged their adjustment to civilian life after the war. The states of fear, anxiety, confusion, pain, cruelty, and hatred that were inherent to American soldiers during the war were also not easy to abandon.

As mentioned earlier, the negative effects of the Second World War have cast a dark shadow over all aspects of life of Americans, including their cultural and literary life. Thus, many writers, led by Albee, described in their works, how a materialistic and capitalist life burdened American individuals with worries, anxieties, and disappointments. Accordingly, they called for a return to ideal human values and a revival of social ties among the members of the American society.

Most critics agree that Albee's plays condemn the cruel treatment of the members of the American society and express his outright rejection of the "American dream" project, which was launched by influential and capitalist personalities to destroy the middle and poor classes. Sense of loss and fear of death are prevalent themes in most of Albee's plays, which often do not have a happy ending to allow the audience or reader to reflect on Albee's message.

In The Zoo Story, the pressures imposed by a capitalist society as well as the isolation, frustration, sense of loss, and lack of communication suffered by an American individual is clearly manifested in the character of Jerry, who is facing a sense of loss and is deprived of the ability to communicate with people in his environment. Albee proposed that "capitalism was occasionally sightless to the American struggles and blind to the reality about them" (The American 40). Albee also explored the class differences and discrimination in the American society as can be seen in the interactions between Jerry and Peter, who represent the poor and the rich, respectively. Albee also explained how such differences intensified the isolation, loneliness, and desire of American individuals to live in a world of illusion after the Second World War. Orr argued that "Albee was one of the great American playwrights who wrote plays about man's isolation and aloneness" (18). 
The American Dream, which was an Albee's most blatant form of criticism of the "American dream" project, presented a realistic picture of the American society where human ties are severed and the ideal cultural values are replaced with modern material concepts. Albee described The American Dream as "an examination of the American Scene, an attack on the substitution of artificial for real values in our society" (Albee The American Dream 4).

In The American Dream, Albee embodied an ideology of the "American dream" project through the character of the Young Man, who represented an empty idea which did not exist on the ground. Through this play, Albee revealed the deceptiveness of the "American dream" project, which he considered a delusion that could not be achieved in reality, and argued that the promoters of this dream were mostly aristocrats who wanted to turn American individuals into a revenue-generating tool. Albee also criticized the materialistic treatment of American families during the post-war period. "It was a condemnation of complacency, cruelty and emasculation and vacuity, a stand against the fiction that everything in this slipping land of ours is peachy keen" (4).

In The Sandbox, Albee explored the feeling of loss among the elderly, the disintegration of families, and the harsh treatment of the elderly. How the character of Mommy tries to drive her mother out of her home paints a depressing picture of the painful relations between parents and their children in American middle-class families. Barrett argued that "we can find such characters are very close to Everyman, but in this play these characters have interaction with the individuals who are not in the mainstream" (50). In this play, Albee suggested that young people should take care of their elders because they would face the same fate in the future. Albee also drew attention to the suffering of the elderly and how they perceived death as a way out of their loneliness, despair, and suffering under the hands of their own families. "She (Grandma) shows that talking with the Angel of Death and even death itself is more merciful than the cruelty of her family" (Gussow 2-3).

Albee revisited the themes of loss, anxiety, and desire to live in a world of illusion in Who's Afraid of Virginia Woolf?,which highlighted the social hypocrisy of families in the American academic community as represented by the characters of Martha and George, who are working as professors in the same university. These characters, along with the bright, young professor Nick, highlighted the unbridled desire of educated American individuals to obtain wealth and secure a respected position. These characters demonstrated how marriage could be used by couples as a tool to achieve their personal goals without considering the feelings of their partners. All these problems cast a dark shadow on the nature of marital relations in the American society during the post-war period. According to Bigsby, "the play is taken as a social criticism of American hypocrisy from beginning to end" (Moral Play 134). Another focus of this play was the individual's failure to face his reality and his tendency to live in a world of illusion to escape his childbearing complex or his inability to meet life's challenges or disappointments, thereby making him a frustrated defeatist who lacks self-confidence. Bloom argued that the play embodies "the fate of the American Dream, which has moved progressively further away from the supposed liberal idealism of those revolutionary principles" (142).

In A Delicate Balance, Tobias and Agnes are anxious characters who fear death and madness. These characters also reflect one's remorse for his past life and his frustration for not being able to correct his previous mistakes. The characters in this play also reflect the feelings and concerns of the human being when approaching the old age, how he tries to escape his responsibilities to his family, and how he ignores the problems being faced by his family members. "Albee creates an experience of the tension between the risk of the reality, and the pain of withdrawal" (McCarthy 140).

The four characters in Seascape demonstrate an individual's hesitation and inability to make decisions. Charlie has an unchangeable personality and tries to defend his ideas despite his lack of conviction, Sarah has an easily renewable personality and readily accepts modern ideas, Nancy has an optimistic personality and seeks to actively and effectively communicate with others, and Leslie has a hesitant personality and is constantly worried 
about making effective decisions. The themes of alienation, anxiety, and fear that are present in most of Albee's plays are also manifested in these characters. "What Mr. Albee has given us here is a play of great density, with many interesting emotional and intellectual reverberations" (Barnes 26).

In sum, most of the themes in Albee's plays reflect the problems being faced by the American society during the post-war period, including the disintegration of families and the loss of social ties. Albee mostly focused on an American individual's state of loss, the disintegration of American families, and the lack of social cohesion in American communities. Other themes, such as fear, hesitation, and a loss, were also touched upon in Albee's plays because of their prevalence in the American society. "The generations move away from practicality towards emasculation; away from the energetic, but the amoral use of power toward an amoral but the inoperative use of power" (Baxandall 85)

\section{A Reflection of the Author's Personal Life}

As mentioned in the introduction to the second chapter, psychological theories reveal that the literary text is related to the subconscious of the author. The writer suppresses his desires in his subconscious and presents them in the form of a socially accepted text. In psychoanalytic theory, Freud linked the life experiences of an author to his literary text and claimed that most characters created by the author are based on real persons whom he has encountered throughout his life and has remained suppressed in his subconscious (Freud 93-110).

In most of his interviews and in his autobiographical book, Albee did not deny that some characters in his plays were based on real people that he encountered in his life. Albee was born on March 12, 1928 to two unknown parents and was adopted by Reid and Francis Albee, two of the wealthiest people in New York at the time. Francis was tall, unlike Reid, who Amacher described as "At all, imperious...lady of formidable aspect" (61).

In the autobiography written by Gussow, Albee admitted that he had known his adoptive mother from his infancy until her death and that he did not like her much because of her authoritarian personality and strictness. However, Albee admired her pride in herself: "I knew my subject—my adoptive mother, whom I knew from my infancy....until her death over sixty years later; it is true, I did not like her much, could not abide her prejudices,... but I did admire her pride, her sense of self." He also did not deny that his adoptive mother had married his adoptive father just for his wealth. He added, “I can't say for sure that she was a tramp or that she married him for money, but I suspect so" (Gussow 28).

In any question or discussion about his childhood, Albee always asserted that he had not been physically abused by his parents and that they had provided him with everything he needed as a child. However, he did not appreciate how his father tried to coerce him into becoming a businessman and he had also become a target of his mother's hatred when Albee was revealed to be a homosexual at the age of 11. Gussow mentioned that "All American life, even forcing him into an engagement (even though he had previously admitted his homosexuality to her)." Although Albee did not deny his homosexuality, he always avoided talking about this topic by merely saying "That was another part of life" (70).

Despite lived his childhood years in an aristocratic family, Albee suffered from the emotional sadism of his mother, who intended to turn him into a child who is free of any defects and always follows the orders of his parents. Sensing that her son is not as perfect as she had wanted him to become, she started humiliating Albee in front of others, thereby giving the young Albee a motive to escape from his house several times. "That was another part of life: living at home, being the dutiful son, engagement and the rest of it. I knew I was supposed to become the kind of person they wanted me to be" (70).

Albee was introduced to many aristocratic people in their community while he was attending or organizing concerts with his parents. However, he did not feel any sense of belongingness in this community. He said that 
he had spent most of his time with the nannies and family drivers and that he was mostly sent to summer camps with his school friends. He did not talk to his father much and his father also did not take the initiative to talk to him about his private life. "I spent most of my time with my nannies or away at summer camp and at school, I didn't see those damn people - my parents - more than six weeks of the year" (Markowitz 19).

Albee believed that his parents adopted him just to fill the void in their aristocratic life caused by the absence of a child in their family who could come along with them in their concerts. He even stated that his parents made him wait for a long time in his room before he could be announced to their guests and that he would be sent back to his room immediately afterward. He had always said that his parents bought him from the orphanage for $\$ 133.3$ to complete their aristocratic family. "They brought me. They paid $\$ 133.30$ for the cost of his 'professional services'" (22). In other words, Albee was not adopted by his parents, because they saw him as an orphan who needed care and affection; instead, they only saw him as a commodity that they could polish and show to others when needed. He said that his adoptive family had given him "money rather than love" (Brantley2006).

In 1949, after a heated argument with his mother, Albee packed his bags, left the house, and never saw his parents again. Albee described his departure as his liberation from an environment in which he suffocated and felt like an outsider. "I had to get out of that stultifying, suffocating environment" (Markowitz 66). He spent the next 10 years in Greenwich Village, New York, where he worked many odd jobs and began to drink alcohol excessively. He also made some unsuccessful attempts to write poetry and short stories during this period.

On his 30th birthday, Albee completed his first play, The Zoo Story, which set him toward a path of creativity and fame in the world of drama. This play was followed by The Sandbox and The American Dream, which were mostly about his clashes with his adoptive parents. The "cruelty of the nuclear family that, it is supposed to be the American Dream" (5).

In one of his interviews, Albee stated that a literary work does not need to be fully associated with the author's life. However, he argued that the author's autobiography should also be read because one can only gain a full logical understanding of the literary text by comparing this text with the biography of its author. He commented that "No worthwhile piece of literature is any good if it has to be related to some biographical factor in the author's life" (Krohn \& Wasserman 14).

In The Zoo Story, Jerry recounted his miserable childhood and sense of loss in a disintegrating family. After his mother's death, Jerry lived at the mercy of his authoritarian aunt, which represented Albee's adoptive mother. Jerry also stated that he developed homosexual tendencies during his adolescence, the same period when Albee's adoptive mother learned about his son's homosexuality. Jerry's sense of loss and distressed personality, as a result of his lack of family relations, reflected the state of loneliness that Albee lived in during his childhood as well as his lack of belonging in the aristocratic community where his family forced him to join. "Capitalism was occasionally sightless to the American struggles and blind to the reality about them" (The American 40).

In The American Dream and The Sandbox, Albee wrote about dominant, strong-willed women "whose lives are inextricably linked with that of their mates" (Gussow 403).These characters were clearly reminiscent of his adoptive mother. Albee described the character of Mommy in The American Dream as strict and taller than her husband, which was the same description that he gave of his adoptive mother. In this play, Albee described the challenges faced by young men when dealing with their mothers. "Albee's plays take the figure of the child in his alternating families and make it the subject of an 'exemplary performance by one generation for the benefit of another'" (Bigsby 153). Albee described the "American dream" project as similar to his difficult life with his adoptive parents. In 2008, The New York Theater Guide reported that The Sandbox and The American Dream represent the biography of Albee. "Through The American Dream and Sandbox are autobiographical, Albee is too complex a playwright to leave it there..." (Gans 3). 
In Who's Afraid of Virginia Woolf?Albee described the character of Martha as a woman who retreated to a world of illusion after her husband failed to achieve her personal goals. Through this work, Albee exposed the deceptiveness of the American capitalist academic society during the post-war period based on his experiences of living in an aristocratic society during his childhood and adolescence. Albee developed a sense of loss and loneliness during his childhood upon realizing that his adoptive parents only used him to fulfill the requirements of an aristocratic family. The same can be said to Martha, who only used her husband as a tool to achieve her personal goals and make her a distinctive woman in her capitalist community. "...the play is taken as a social criticism of American hypocrisy from beginning to end" (Moral Play 134).

Although many characters in Albee's plays are based on characters that he personally encountered during his life, Three Tall Women remains his most personal play through which he described his difficult relationship with his adoptive mother, whose death inspired Albee to write the play. "It was directly inspired by his own adoptive mother, a domineering, Amazonian woman" (30). The Sandbox and Three Tall Women presented the figure of the Young Man who is represent the characters of Albee in his family. By doing so, the playwright took the "people of his imagination" (Gussow 403).

\section{Conclusion}

Most of Albee's characters were inspired by certain details about his life, including his adoption, his hatred of the materialistic capitalist community where he was mixed up during his early life, his homosexuality as a teenager, and the cruel treatment he received from his adoptive mother. Nevertheless, Albee mentioned that he did not write about himself directly in any of his plays, except for Three Tall Women, where he saw himself in the character of the child. Albee described this work by saying "It was an exorcism. And one can see in (A) the roots of the controlling women who abound in the rest of his oeuvre" (56).

Albee's deprivation of any paternal tenderness during his childhood, his complex relationship with his adoptive mother, and his rejection of an aristocratic society that is based on social hypocrisy and materialism are all reflected in many of his literary works where characters are facing a state of loss, anxiety, and lack of belongingness to their society.

\section{REFERENCES}

1. Albee, Edward. The American Dream. London: Samuel French,(1961):4-52

2. Amacher, Richard E. Edward Albee. Boston: G.K.Hall, (1982): 61-175.

3. Barnes, Clive. "Theater: Albee's Adventurous Plays.” New York Times 39 (2006):26

4. Baxandall, Lee. "The Theater of Edward Albee." The Modern American Theater: ACollection of Essays. Englewood Cliffs, NJ: Prentice-Hall, 1967. 50-98.

5. Bigsby, C. W. E. "Who's Afraid of Virginia Woolf? Edward Albee's Morality Play." Journal of American Studies 1.2 (1967): 140 -268.

6. Bloom, Harold, ed.Edward Albee. Chelsea House Publishers, (1987):142.

7. Brantley, Ben. "Marriage as Blood Sport: A No-Win Game." The New York Times March 2005: E1. LexisNexis. University of Arizona Library. 24 January 2006.

8. Freud, Sigmund. .Ageneral Introduction to psychonalalysis. London: Published by PdF Backsword, (1958):93-110.

9. Gans, Andrew.'Albee’s 'Dream' and 'Sandbox' ” Begin Previews March 21

10. Gussow, Mel. Edward Albee: A Singular Journey. New York: Simon \& Schuster, (1999):20 -403. 
Sense of Loss in Albee's Plays

11. Kaber, Kadhim.Jingjing, Guo. “Materialist Society in Albee's Who's Afraid of Virginia Woolf?”English Language and Literature Studies, Canadian Center of Science and Education Vol. 8: 1, March 2018

12. Kaber, Kadhim. Jingjing, Guo“FAMILY DISINTEGRATION IN ALBEE'S THE SANDBOX”European Journal of English Language and Literature Studies Vol.6, No.1, pp.9-13, February 2018

13. Kaber,Kadhim.JingjingGuo"Albee's Plays in the Light of Psychological Theories" English Language Teaching; Vol. 11, No. 4; 2018

14. Markowitz, Dan. "Albee Mines his Larchmont Childhood." The New York Times on the Web 28 August (1994):66

15. McCarthy, Gerry. Edward Albee. New York: St. Martin's Press, (1987):140- 340

16. Wasserman, Julian N. Edward Albee. An Interview and Essays. Houston: The University of St. Thomas,(1983): 121- 40 .

Citation: Kadhim Hatem Kaibr, Guo Jingjing, "Sense of Loss in Albee's Plays". American Research Journal of Humanities and Social Sciences, vol 4, no. 1, 2018, pp. 1-6.

Copyright (c) 2018 Kadhim Hatem Kaibr, Guo Jingjing, This is an open access article distributed under the Creative Commons Attribution License, which permits unrestricted use, distribution, and reproduction in any medium, provided the original work is properly cited. 